\title{
Analisis Kemiskinan Spasial Dan Kaitannya Dengan Sertifikasi Tanah Dan Penggunaan Lahan Pertanian Di Kabupaten Mamuju
}

\author{
A Spatial Analysis of Poverty and Relationship with Land \\ Certification and Agricultural Land Use in Mamuju Regency
}

Ade Irawadi ${ }^{1}$, Bambang Juanda ${ }^{2}$, Khursatul Munibah ${ }^{3}$

Diterima: 29 Desember 2017

Disetujui: 20 Oktober 2018

\begin{abstract}
Abstrak: Permasalahan kemiskinan masih merupakan isu strategis di Kabupaten Mamuju Provinsi Sulawesi Barat. Tingkat kemiskinan pada tahun 2015 sebesar 6.7\%, tetapi laju penurunannya setiap tahun masih sangat lambat. Memahami hubungan antara kemiskinan dengan faktor-faktor yang mempengaruhinya adalah penting untuk menentukan kebijakan yang tepat untuk penanggulangan kemiskinan di Kabupaten Mamuju. Penelitian ini bertujuan: (1) menganalisis pola spasial kemiskinan; dan (2) menganalisis kaitan kemiskinan dengan faktor-faktor yang mempengaruhinya secara spasial. Penelitian ini menggunakan data cross section tahun 2015 dari 97 desa/kelurahan. Data yang digunakan adalah data tingkat kemiskinan, sertifikasi tanah, penggunaan lahan pertanian, tenaga kerja di sektor industri, jarak ke ibukota dan dana desa. Analisis spasial kemiskinan dilakukan dengan pendekatan Indeks Moran untuk mengetahui pola spasial kemiskinan. Analisis keterkaitan antara tingkat kemiskinan setiap desa/kelurahan dengan faktor yang diduga mempengaruhinya menggunakan pendekatan Geographically Weighted Regression (GWR). Hasil analisis spasial kemiskinan menunjukkan bahwa tingkat kemiskinan desa/kelurahan di Kabupaten Mamuju polanya bersifat mengelompok (clustered). Hasil analisis GWR menunjukkan bahwa faktor jumlah sertifikat tanah, persentase luas penggunaan lahan perkebunan, lahan sawah, persentase luas lahan tambak, persentase luas lahan tegalan/ladang, persentase tenaga kerja di sektor industri mikro dan kecil, jarak ke ibukota dan dana desa terbukti berpengaruh signifikan secara bervariasi terhadap tingkat kemiskinan desa/kelurahan.
\end{abstract}

Kata kunci: gwr, sertifikasi tanah, penggunaan tanah, kemiskinan

Abstract: The poverty is still a strategic issue in Mamuju Regency, West Sulawesi. In 2015 the poverty rate is $6.7 \%$, but the decline of every year is still very slow. Understanding the relationship between poverty and the factors that influence it is important to determine the right policies for poverty alleviation in Mamuju Regency. This study aims to: (1) analyze spatial patterns of poverty; and (2) analyze the relationship of poverty with factors that influence spatially. This study used cross sectional village level data of 97 villages/kelurahan in the Mamuju Regency. The data used are poverty, land certification, agricultural land use, labor in industrial sector, distance to

\footnotetext{
${ }^{1}$ Program Studi Ilmu Perencanaan Pembangunan Wilayah dan Perdesaan, Sekolah Pascasarjana, Institut Pertanian Bogor

2 Departemen Ilmu Ekonomi, Fakultas Ekonomi dan Manajemen, Institut Pertanian Bogor

3 Departemen Ilmu Tanah dan Sumberdaya Lahan, Fakultas Pertanian, Institut Pertanian Bogor
}

Korespondensi: adeirawadi@gmail.com 
capital and village fund. A spatial analysis of poverty uses Moran Index approach to find out spatial pattern of poverty in Mamuju Regency. Analysis of the relationship between the poverty level of each village/kelurahan with the factors influence it using the Geographically Weighted Regression (GWR) approach. The result of spatial analysis of poverty indicates that the poverty level of the village/kelurahan in Mamuju Regency is clustered. The result of GWR analysis shows that the land certificates, the percentage of land area of plantation, paddy field, fields area, and fishpond, percentage of labor in micro and small industry sector, distance to the capital and village fund proved to have significant effect varying to village poverty level.

Keywords: gwr, land certification, land use, poverty

\section{PENDAHULUAN}

Permasalahan kemiskinan masih menjadi perhatian utama pemerintah. Berbagai program penanggulangan kemiskinan telah dilaksanakan dan diharapkan sejalan dengan visi Pemerintah yang tertuang dalam salah satu dari sembilan agenda prioritas (NAWACITA), yaitu "Membangun Indonesia dari pinggiran dengan memperkuat daerahdaerah dan desa dalam rangka negara kesatuan". Kebijakan penanggulangan kemiskinan selama ini dilakukan melalui pendekatan sektoral, tanpa mempertimbangkan aspek spasial. Penggunaan pendekatan spasial dibutuhkan untuk memberikan gambaran mengenai variasi kemiskinan serta keragaman faktor-faktor yang mempengaruhinya.

Kabupaten Mamuju merupakan salah satu kabupaten di Provinsi Sulawesi Barat yang memiliki tingkat kemiskinan yang cukup rendah, yaitu hanya sebesar $6.7 \%$ dibandingkan dengan tingkat kemiskinan tingkat provinsi sebesar 12.4\% (BPS 2016). Analisis spasial kemiskinan akan memberikan informasi apakah tingkat kemiskinan yang cukup rendah di Kabupaten Mamuju merata di semua wilayah atau terjadi pengelompokan tingkat kemiskinan di wilayah tersebut. Menurut Nurwati (2008), kemiskinan merupakan masalah multidimensi karena berkaitan dengan ketidakmampuan akses secara ekonomi, sosial budaya, politik dan partisipasi dalam masyarakat. Penelitian ini dilakukan melalui pendekatan spasial terhadap tingkat kemiskinan, perekonomian wilayah, geografis dan pengaruh kebijakan pemerintah dalam mereduksi kemiskinan.

Aspek perekonomian merupakan salah satu pertimbangan utama dalam menganalisis kemiskinan, pendekatan yang dilakukan yaitu dengan menganalisis struktur ekonomi penyusun PDRB. Jika dilihat pada struktur ekonomi penyusun PDRB, Sektor Pertanian, Kehutanan dan Perikanan memberikan kontribusi terbesar yaitu sebesar $36.41 \%$ dengan 59.10\% tenaga kerja adalah di sektor pertanian (BPS Kab. Mamuju 2016). Sebagai sektor basis dalam perekonomian, perlu dianalisis pola penggunaan lahan pertanian karena kaitannya secara langsung dengan kinerja sektor pertanian. Aspek pengaruh program pemerintah penanggulangan kemiskinan difokuskan pada program strategis pemerintah yang sedang berjalan, yaitu Program Percepatan Sertifikasi tanah dan Program Dana Desa. Indikasi kegagalan program terjadi ketika pelaksanaan program tidak mempertimbangkan sasaran yang tepat dan tanpa prioritas wilayah pelaksanaan yang dapat memberikan percepatan pengurangan kemiskinan. Sedangkan aspek geografis wilayah yang berpengaruh terhadap kemiskinan di antaranya kondisi geografis Kabupaten Mamuju yang berbukit, akses jalan yang sangat terbatas dan terbatasnya potensi sumberdaya alam yang dapat dimanfaatkan karena sebagian besar wilayahnya merupakan kawasan hutan.

Beberapa studi telah dilakukan dalam menangani masalah kemiskinan dengan pendekatan spasial, ada beragam saran dari studi sebelumnya mengenai analisis spasial kemiskinan dan hubungan antara kemiskinan dengan kepemilikan sertifikasi tanah dan dengan penggunaan lahan pertanian. Susila (2011) menunjukkan bahwa hasil analisis visual spasial deskriptif dan autokorelasi spasial (dengan Indeks Geary dan Moran) terlihat bahwa sebaran spasial persentase penduduk miskin dan kepadatan penduduk miskin cenderung membentuk pola mengelompok (kantong kemiskinan). Nashwari (2016) menyimpulkan 
bahwa dalam analisis spasial, unit analisis yang lebih kecil terbukti lebih sensitif dan mampu menangkap keragaman kemiskinan lebih spesifik daripada unit yang lebih besar. Beberapa penelitian mengenai lahan pertanian menunjukkan adanya hubungan positif antara lahan sawah dengan kemiskinan (Artino 2017), sementara yang lain menunjukkan hubungan negatif (Nashwari 2016). Permatasari (2015) menghasilkan kesimpulan studi bahwa share pertanian terhadap kemiskinan adalah negatif. Hasil studi memperkuat keyakinan perlunya mendorong lebih kuat lagi pembangunan pertanian untuk mengurangi angka kemiskinan. Menurut Anselin (1988) bahwa setiap daerah memiliki keterkaitan dengan daerah lainnya. Oleh karena itu, pemahaman yang lebih baik tentang tingkat kemiskinan dan hubungannya satu sama lain dengan faktor yang mempengaruhinya di Kabupaten Mamuju diperlukan dalam upaya merancang kebijakan pengurangan kemiskinan. Memahami apakah kepemilikan sertifikasi tanah dan penggunaan lahan pertanian benar-benar membantu pengentasan kemiskinan di Kabupaten Mamuju akan memberikan wawasan berharga untuk merancang strategi pengentasan kemiskinan. Oleh sebab itu penelitian ini bertujuan untuk mengetahui:

1. Bagaimana pola spasial kemiskinan di Kabupaten Mamuju?

2. Bagaimana pengaruh lahan bersertifikat dan penggunaan lahan pertanian, serta faktorfaktor lainnya terhadap kemiskinan di Kabupaten Mamuju?

\section{METODE}

\section{Lokasi dan Waktu Penelitian}

Lokasi penelitian yaitu di Kabupaten Mamuju, Provinsi Sulawesi Barat yang terdiri dari 85 desa dan 11 kelurahan (97 unit penelitian). Penelitian dilakukan mulai bulan Maret 2017 sampai dengan Desember 2017.

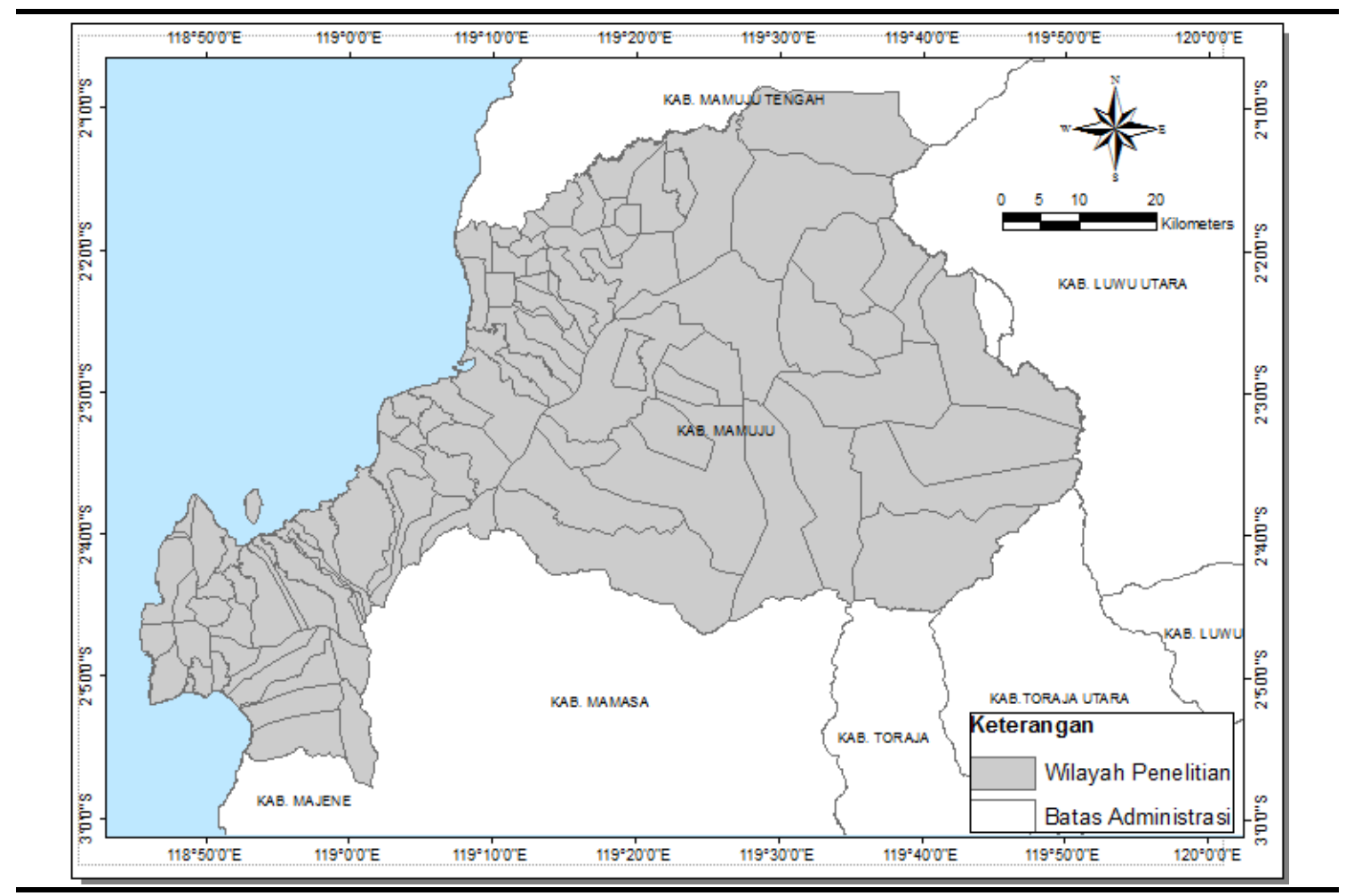

Gambar 1 Peta Lokasi Penelitian 


\section{Jenis dan Sumber Data}

Data yang digunakan dalam penelitian ini adalah data sekunder meliputi: data kemiskinan yang bersumber dari Basis Data Terpadu (BDT) Tim Nasional Percepatan Penanggulangan Kemiskinan (TNP2K) dan Badan Pusat Statistik (BPS); peta administrasi wilayah, peta penggunaan lahan, peta kawasan hutan dan data sertifikat tanah yang didapatkan dari Kantor Pertanahan Kabupaten Mamuju; data dana desa dari Badan Pemberdayaan Masyarakat Desa Kabupaten Mamuju (BPMD Kab.Mamuju); dan data gambaran umum wilayah dan potensi desa yang diperoleh BPS Kabupaten Mamuju.

\section{Analisis Data}

\section{Analisis Pola Spasial Kemiskinan di Kabupaten Mamuju}

\section{Analisis Indeks Moran Global}

Analisis Indeks Moran Global digunakan mengidentifikasi dan mengetahui adanya autokorelasi spasial variabel tingkat kemiskinan (Y) antar unit amatan (desa/kelurahan). Juanda (2009) menyatakan bahwa autokorelasi dapat juga terjadi dalam data Cross Section, untuk data cross section dengan objek pengamatan kecamatan misalnya, biasanya kita sebut autokorelasi spasial (spatial autocorrelation). Uji autokorelasi dalam penelitian ini menggunakan tool Spatial Autocorrelation (Indeks Moran) dari software ArcGis 10.2.1. Tool akan menghitung autokorelasi spasial berdasarkan nilai atribut dan lokasi dari masing-masing desa/kelurahan.

\section{Analisis Moran Lokal Anselin}

Analisis Moran Lokal Anselin digunakan untuk mengidentifikasi dan mengelompokkan wilayah desa yang memiliki kemiripan yang nyata untuk tingkat kemiskinan. Analisis pola spasial kemiskinan akan menggunakan tool Cluster and Outlier Analysis (Anselin Local Moran Index) dari software ArcGis 10.2.1.

\section{Analisis Deskriptif berbasis Pemetaan Tematik Kemiskinan}

Analisis ini dimaksudkan untuk melihat pola sebaran kemiskinan yang ada di Kabupaten Mamuju berdasarkan pemetaan tematik tingkat kemiskinan desa/kelurahan. Analisis ini juga untuk memperkuat hasil dari analisis Indeks Moran Global dan Indeks Moran Lokal.

\section{Analisis Kaitan Sertifikasi Tanah, Penggunaan Lahan Pertanian dan Faktor lain yang diindikasikan berpengaruh terhadap Kemiskinan}

\section{Pemodelan Regresi Terboboti Spasial (GWR)}

Model GWR adalah suatu model regresi yang diubah menjadi model regresi yang terboboti (Fotheringham et al. 2002). Variabel Y ditaksir dengan variabel prediktor yang masing-masing koefisien regresinya tergantung pada lokasi dimana data tersebut diamati. Secara khusus berdasarkan variabel independent. jumlah sertifikat, luas lahan sawah, luas perkebunan, luas ladang/tegalan, luas tambak, jarak ke ibukota kabupaten, serta tingkat angkatan kerja di sektor industri mikro dan kecil dan dana desa, maka dapat dibuat sebuah model geographical weighted regression (GWR) yaitu: 
Kemiskinan $=\beta_{0}$ (ui,vi) $+\beta_{1 \mathrm{i}}$ (ui,vi) Jumlah Sertifikat $+\beta_{2 \mathrm{i}}$ (ui,vi) Sawah $+\beta_{3 \mathrm{i}}$ (ui,vi) Perkebunan $+\beta_{4 i}$ (ui,vi)Ladang/Tegalan $+\beta_{5 i}$ (ui,vi) Tambak $+\beta_{6 i}$ (ui,vi) Jarak ke Ibukota Kabupaten $+\beta_{7 \mathrm{i}}$ (ui,vi) Industri MK $+\beta_{8 \mathrm{i}}$ (ui,vi) Dana Desa $+\varepsilon i$

Keterangan:

$\begin{array}{ll}\beta_{0} & =\text { intercept } \\ \beta_{1 \mathrm{i} \ldots .} \beta_{8 \mathrm{i}} & =\text { koefisien peubah di desa/kelurahan i } \\ \text { (ui,vi) } & =\text { koordinat lintang, bujur dari lokasi pengamatan ke- } \mathrm{i}\end{array}$

\section{Uji Signifikansi Variabel Secara Spesifik Lokasi}

Untuk setiap variabel X yang digunakan dalam GWR, dilakukan uji signifikansi pada taraf nyata 0.05 untuk melihat adanya pengaruh dari masing-masing variabel tersebut terhadap kemiskinan di masing-masing desa/kelurahan. Uji signifikansi dapat dilakukan dengan hipotesis sebagai berikut:

$$
\begin{aligned}
& \mathrm{H}_{0}=\beta_{k}\left(u_{i}, v_{i}\right)=0 \\
& \mathrm{H}_{1}=\beta_{k}\left(u_{i}, v_{i}\right) \neq 0 \text { atau }\left(\beta_{k}>0 \text { atau } \beta_{k}<0\right) ; \mathrm{k}=1,2, \ldots, \mathrm{p}
\end{aligned}
$$

Statistik uji:

$$
\wedge \quad \mathbf{t}_{\text {hit }}=\frac{\beta_{k}\left(u_{i}, v_{i}\right)-\beta_{k}\left(u_{i}, v_{i}\right)}{\operatorname{Se}\left(\beta_{k}\left(u_{i}, v_{i}\right)\right)}
$$

\section{Keterangan:}

$\widehat{\beta_{k}}\left(u_{i}, v_{i}\right)$ : nilai observasi variabel prediktor ke- k pada lokasi pengamatan ke-i $\operatorname{Se}\left(\widehat{\beta_{k}}\left(u_{i}, v_{i}\right)\right)$ :standard error variabel prediktor ke- k pada lokasi pengamatan ke-i

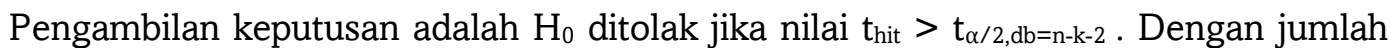
unit penelitian 97 desa/kelurahan, maka $\mathrm{t}_{\alpha / 2, \mathrm{db}=\mathrm{n}-\mathrm{k}-2}$ dapat ditentukan nilainya: $\mathrm{t}_{0.05 / 2,97-8-2}=$ $\mathrm{t}_{0.025,87}=1.98761$.

Hasil dari uji signifikansi masing-masing variabel untuk masing-masing desa/kelurahan memberi informasi pengaruh dari variabel-variabel tersebut dalam dua arah terhadap kemiskinan, dimana pengaruhnya bisa saja bersifat mengurangi kemiskinan atau meningkatkan kemiskinan, tergantung pada angka koefisien yang didapatkan oleh masing-masing variabel. Angka koefisien yang bernilai negatif dapat diartikan bahwa variabel tersebut berpengaruh dalam menurunkan kemiskinan di desa tersebut. Sedangkan jika nilai koefisiennya positif berarti sebaliknya bahwa variabel tersebut akan meningkatkan kemiskinan di desa tersebut.

\section{Pemetaan Lokasi Signifikan Variabel yang Mempengaruhi Kemiskinan}

Berdasarkan hasil gwr dan dilakukan uji signifikansi variabel pada taraf nyata 0.05 , dapat dipetakan wilayah yang memiliki kemiripan faktor-faktor yang berpengaruh terhadap kemiskinan. Pemetaan faktor yang berpengaruh signifikan akan memberikan informasi secara spasial wilayah yang dapat diimplementasikan kebijakan yang sama untuk pengentasan kemiskinan. Implementasi kebijakan dapat diterapkan berbasis wilayah yang memiliki kesamaan faktor yang berpengaruh nyata dalam mereduksi kemiskinan. 


\section{HASIL DAN PEMBAHASAN}

\section{Analisis Kemiskinan Spasial}

\section{Analisis Indeks Moran Global}

Berdasarkan hasil output Indeks Moran (Gambar 2) dari data tingkat kemiskinan desa/kelurahan, terlihat bahwa pola spasial sebaran kemiskinan bersifat menggerombol (clustered). Nilai Indeks Moran yang dihasilkan bernilai positif yaitu 0,188973, yang juga berarti terdapat autokorelasi spasial kemiskinan antar desa/kelurahan dan secara spasial pola sebarannya bersifat menggerombol (clustered). Hasil Indeks Moran Global memberikan kesimpulan bahwa terjadi pengelompokkan kemiskinan di wilayah Kabupaten Mamuju dimana terdapat desa/kelurahan yang memiliki nilai amatan (tingkat kemiskinan) yang hampir sama dengan desa/kelurahan yang letaknya saling berdekatan atau bertetangga.

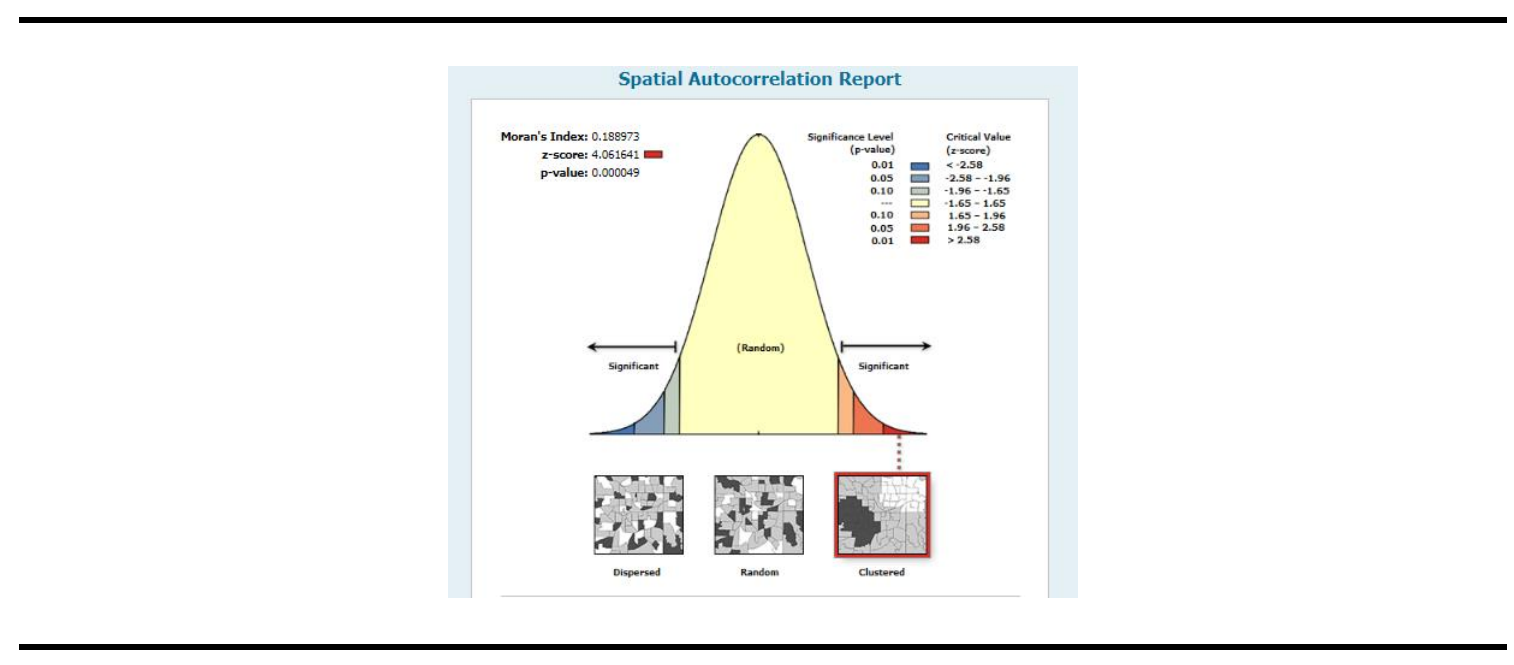

Gambar 2 Output Indeks Moran Data Persentase Kemiskinan

\section{Analisis Moran Lokal Anselin dan Analisis Deskriptif berbasis Pemetaan Tematik Kemiskinan}

Berdasarkan Analisis Moran Lokal Anselin terdapat empat pengelompokan desa berdasarkan tingkat kemiskinan, dimana terdiri dari dua kelompok high-high cluster dan dua kelompok low-low cluster (Gambar 3a). Sedangkan kategori high-low outliers, dimana desa/kelurahan dengan tingkat kemiskinan tinggi tetapi dikelilingi oleh desa/kabupaten dengan tingkat kemiskinan rendah tidak ditemukan di wilayah penelitian. Begitu juga kategori low-high outlier, dimana desa/kelurahan dengan tingkat kemiskinan rendah tetapi dikelilingi oleh desa/kelurahan dengan tingkat kemiskinan yang tinggi juga tidak ditemukan di Kabupaten Mamuju.

Berdasarkan analisis deskriptif berbasis pemetaan tematik kemiskinan (Gambar 3b), didapatkan informasi: (a) wilayah desa/kelurahan yang memiliki persentase kemiskinan di atas rata-rata kemiskinan Provinsi Sulawesi Barat (>12.41\%) sejumlah 29 desa/kelurahan; (b) wilayah desa/kelurahan yang memiliki persentase kemiskinan di antara tingkat kemiskinan kabupaten dan tingkat kemiskinan tingkat provinsi (6.7\%-12.41\%) sejumlah 30 desa/kelurahan; dan (c) wilayah desa/kelurahan yang memiliki persentase kemiskinan di bawah rata-rata kemiskinan kabupaten (6.7\%) adalah sebanyak 38 desa/kelurahan. Dari hasil pemetaan ini terlihat bahwa tingkat kemiskinan di Kabupaten Mamuju sangat 
bervariasi dan terdapat ketimpangan tingkat kemiskinan antar desa/kelurahan dan pengelompokan desa dengan tingkat kemiskinan yang hampir sama.

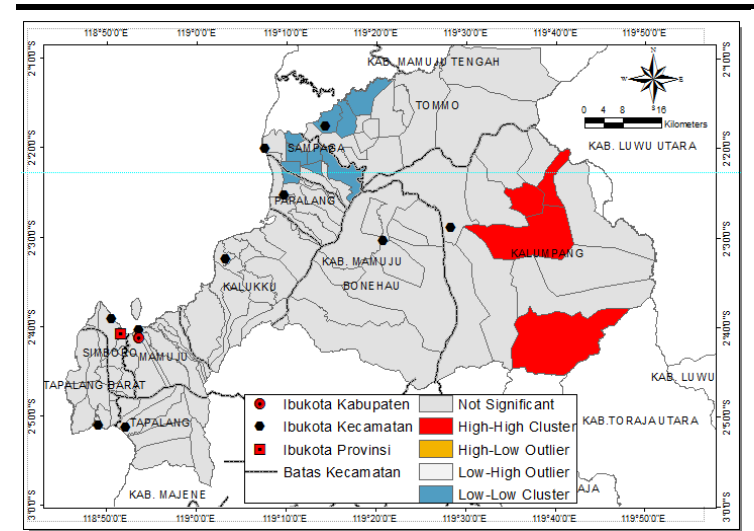

(a)

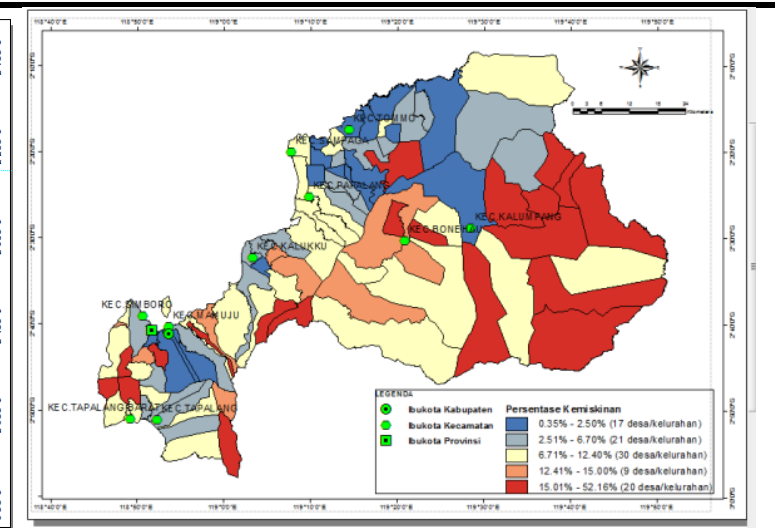

(b)

Gambar 3 (a) Output Indeks Moran Lokal Anselin; dan (b) Peta Sebaran Tingkat Kemiskinan

\section{Analisis Keterkaitan Sertifikasi Tanah, Penggunaan Lahan Pertanian dan Faktor Lain yang diindikasikan Berpengaruh terhadap Kemiskinan}

\section{Pemodelan Regresi Terboboti Spasial (GWR)}

Hasil estimasi GWR menunjukkan bahwa koefisien determinasi $\left(\mathrm{R}^{2}\right)$ sebesar 0.6497. Nilai $\mathrm{R}^{2}$ ini menjelaskan bahwa variasi nilai variabel $\mathrm{Y}$ dapat dijelaskan oleh model sebesar 64.97\%. Dalam penelitian ini berarti variasi kemiskinan di Kabupaten Mamuju dapat dijelaskan oleh faktor sertifikasi tanah, penggunaan lahan pertanian, persentase tenaga kerja di sektor industri, jarak desa/kelurahan ke ibukota kabupaten dan dana desa sebesar $64.97 \%$, sedangkan selebihnya (35.03\%) ditentukan oleh faktor lain yang belum dimasukkan dalam model penelitian ini.

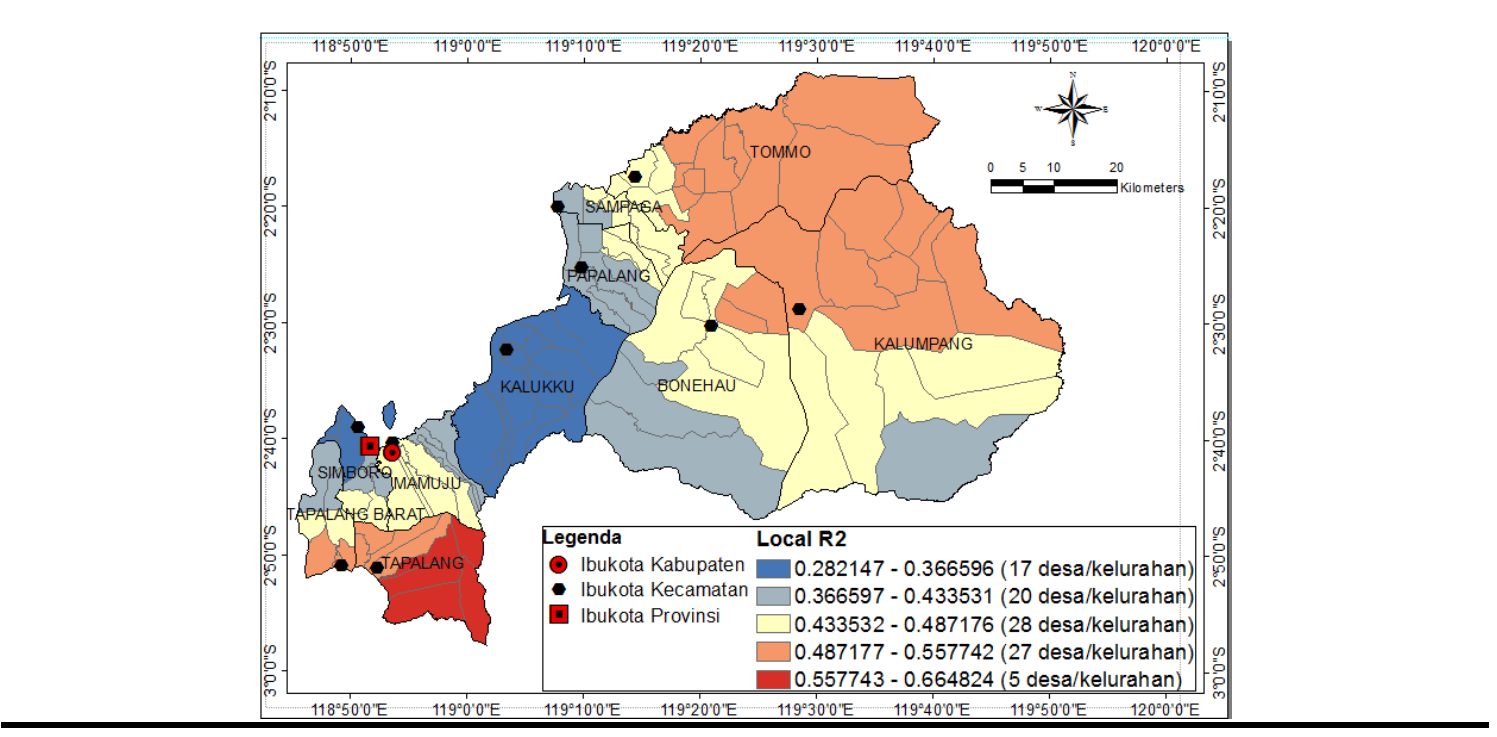

Gambar 4 Sebaran Nilai $\mathbf{R}^{2}$ untuk Setiap Desa/Kelurahan 
Pemodelan GWR menghasilkan persamaan regresi yang bersifat lokal dan bervariasi di setiap unit wilayah. Secara lokal masing-masing desa/kelurahan memiliki koefisien determinasi $\left(\mathrm{R}^{2}\right)$ yang berbeda karena setiap desa/kelurahan memiliki variabel dan koefisien variabel yang berbeda-beda (Gambar 4)

\section{Uji Signifikansi dan Pemetaan Lokasi Signifikan Variabel yang Berpengaruh terhadap Kemiskinan}

Salah satu kelebihan model GWR adalah nilai masing-masing variabel dapat dipetakan untuk setiap unit amatan, sehingga secara deskriptif mampu menjelaskan variasi spasial dari masing-masing variabel terhadap kemiskinan di wilayah tersebut.

\section{Pengaruh Sertifikasi Tanah terhadap Kemiskinan}

Pada taraf nyata 0.05 didapatkan hasil bahwa tidak di semua wilayah Kabupaten Mamuju sertifikat tanah berpengaruh terhadap kemiskinan. Pada Gambar 5 dapat dilihat bahwa angka koefisien variabel sertifikasi tanah bernilai negatif untuk 56 desa/kelurahan. Hal ini berarti sertifikat memberikan pengaruh dalam penurunan kemiskinan di 56 desa/kelurahan. Berdasarkan hasil GWR, dapat memberikan arahan bahwa program percepatan sertifikasi tanah yang akan dilaksanakan lebih efektif jika diprioritaskan pada wilayah atau desa/kelurahan yang memiliki angka koefisen terkecil karena mempunyai pengaruh paling besar untuk mengurangi kemiskinan.

Transmisi pengaruh sertifikat dalam menurunkan tingkat kemiskinan adalah sertifikasi tanah akan mendorong naiknya harga tanah, sehingga mendorong masyarakat untuk mengagunkan sertifikat di perbankan untuk mendapatkan modal usaha. Modal usaha dapat digunakan untuk meningkatkan skala usaha yang sudah ada, atau digunakan untuk alternatif usaha lain sehingga dapat meningkatkan pendapatan rumah tangga. Hasil akhirnya adalah peningkatan pendapatan masyarakat sehingga diharapkan dapat mendorong berkurangnya angka kemiskinan di desa/kelurahan tersebut.

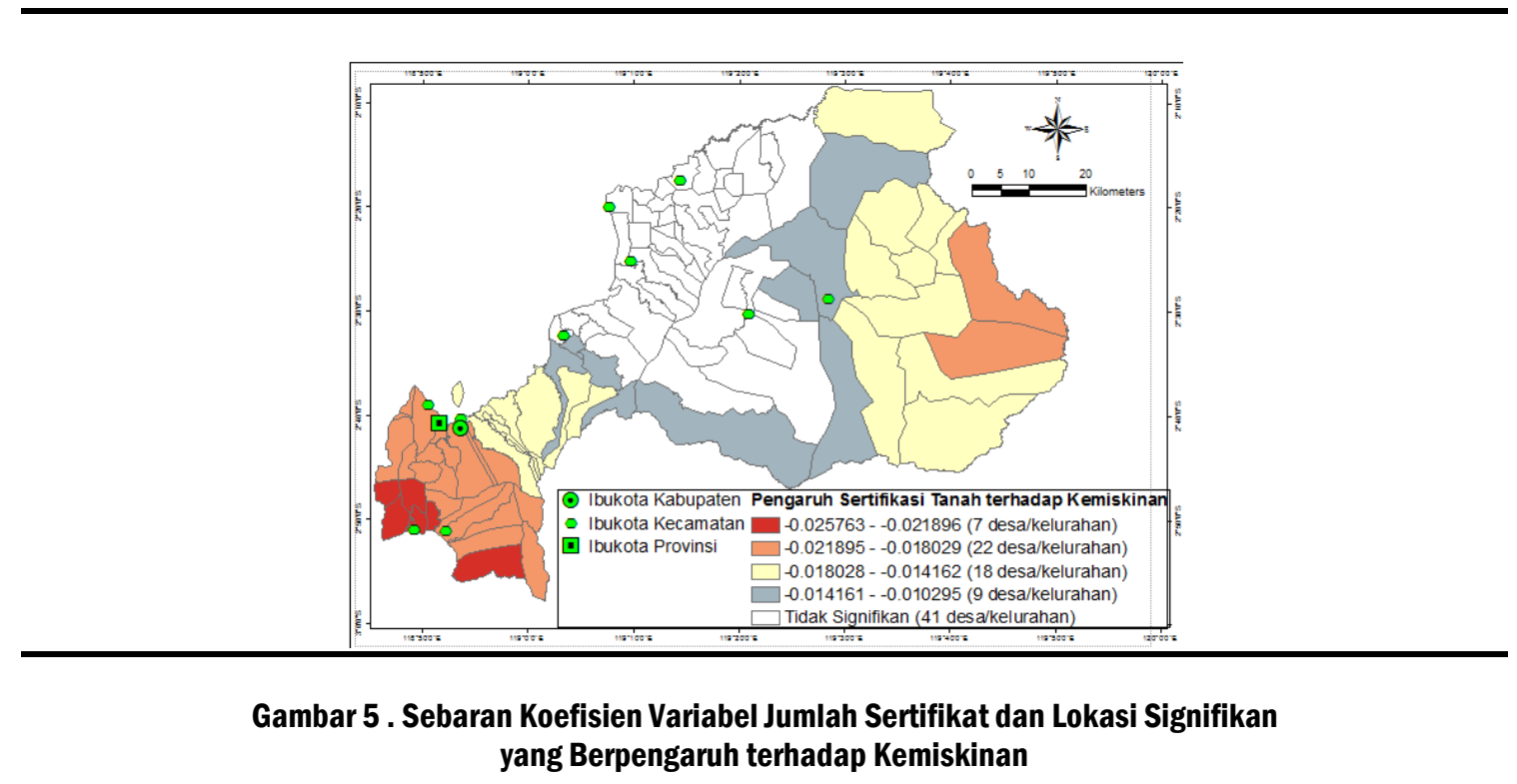

Studi yang membahas mengenai kepemilikan tanah, kredit, modal dan hubungannya dengan kemiskinan telah dilakukan oleh Baiyegunhi dan Fraser (2014), yang menemukan bahwa faktor kepemilikan tanah, ketersediaan kredit, modal merupakan beberapa faktor yang dapat mempengaruhi status kemiskinan petani. Penelitian mengenai pengaruh akses kredit terhadap kemiskinan juga telah dilakukan oleh Adetayo (2014) di Nigeria, dimana 
penelitian ini menemukan faktor yang mempengaruhi kemiskinan petani adalah pendidikan kepala rumah tangga dan akses kredit.

\section{Pengaruh Lahan Pertanian terhadap Kemiskinan}

Berdasarkan hasil uji signifikansi pengaruh lahan pertanian terhadap kemiskinan di Kabupaten Mamuju, didapatkan hasil bahwa perkebunan berpengaruh secara signifikan di sebagian besar wilayah Kabupaten Mamuju, kecuali di beberapa desa/kelurahan di wilayah bagian selatan. Sebanyak 65 desa/kelurahan terbukti tingkat kemiskinannya dipengaruhi secara signifikan oleh lahan kebun dan perkebunan (Gambar 6a).
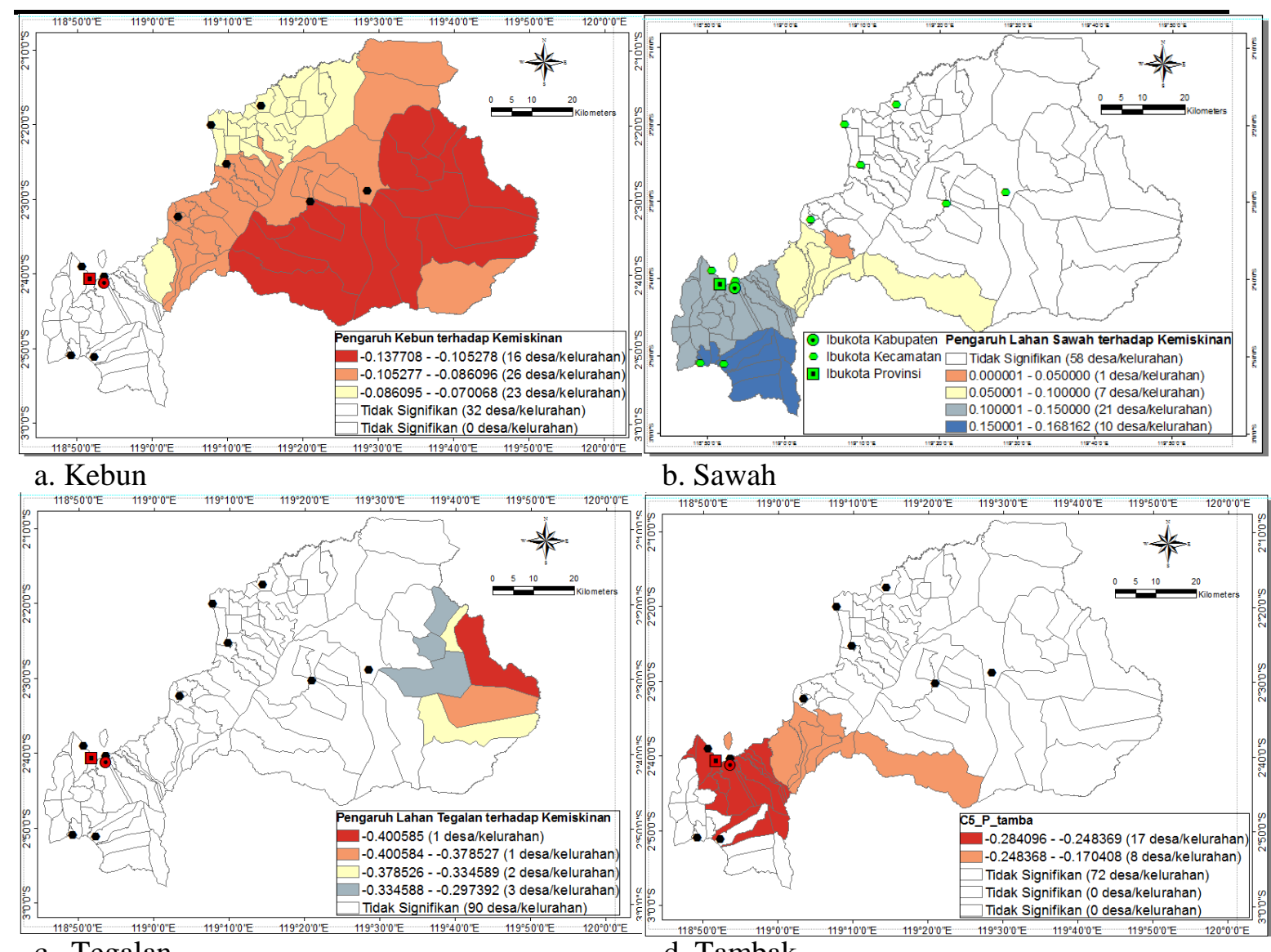

b. Sawah

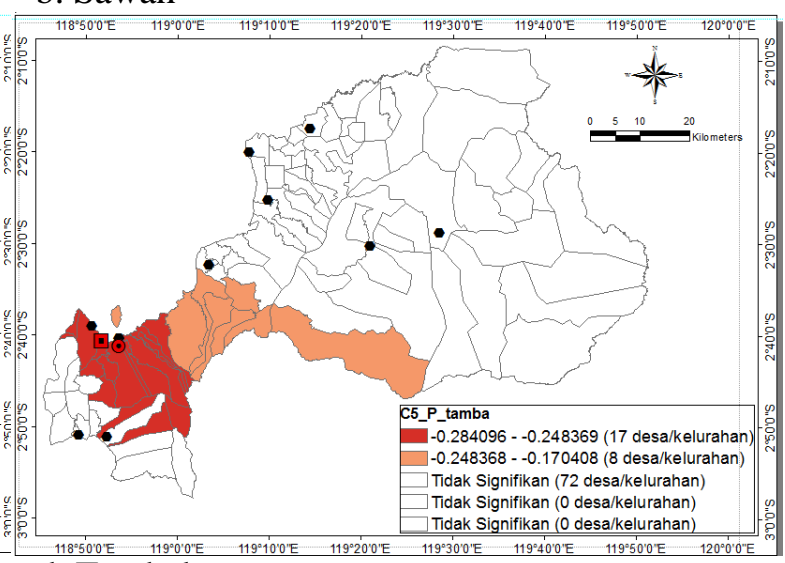

c. Tegalan

d. Tambak

Gambar 6. Sebaran Koefisien Variabel Lahan Pertanian dan Lokasi Signifikan yang Mempengaruhi Kemiskinan

Lahan sawah tidak berpengaruh signifikan dalam mereduksi kemiskinan (Gambar $5 b)$, bahkan di wilayah bagian selatan keberadaan lahan sawah yang rata-rata luasannya kecil, jika lahan sawah bukan merupakan lahan yang ditetapkan sebagai Lahan Pertanian Pangan Berkelanjutan (LP2B), memiliki kecenderungan akan lebih baik jika diarahkan ke penggunaan pertanian lainnya seperti tambak atau kebun. Jika merupakan lahan LP2B, akan lebih baik jika para petani memiliki penghasilan tambahan lainnya selain bertani sawah dan melalui upaya peningkatan hasil panen. Amri et al. (2016) dalam penelitiannya menjelaskan bahwa untuk meningkatkan kesejahteraan kehidupan petani dalam upaya pengentasan kemiskinan adalah peningkatan hasil panen melalui pengairan yang memadai, pembibitan, pupuk dan pemeliharaan yang sesuai. Dalam hal ini, upaya melalui peningkatan hasil panen melalui perbaikan irigasi, kesesuain bibit, pupuk dan cara 
pemeliharaan merupakan alternatif solusi yang tepat dibandingkan memperluas lahan pertanian sawah.

Lahan tegalan hanya memiliki kecenderungan dapat mereduksi kemiskinan di wilayah bagian timur yaitu sebagian wilayah Kecamatan Kalumpang, sedangkan lahan tambak memiliki kecenderungan dapat dikembangkan dan mereduksi kemiskinan di wilayah bagian barat Kabupaten Mamuju, terutama di sekitar ibukota Kabupaten. Peningkatan luas lahan tegalan dan tambak di lokasi yang sesuai akan dapat menurunkan tingkat kemiskinan di desa/kelurahan tersebut.

\section{Pengaruh Sektor Industri, Jarak dan Dana Desa terhadap Kemiskinan}

Hasil studi menemukan bahwa sektor industri memiliki kecenderungan mengurangi kemiskinan di wilayah bagian selatan, terutama di sekitar ibukota Kabupaten. Sedangkan di wilayah yang jauh dari ibukota, sektor industri tidak mampu mengurangi kemiskinan karena pengaruh akses jalan yang masih terbatas antar desa dan menuju pusat perekonomian. Dana desa memiliki kecenderungan dapat mereduksi kemiskinan di 68 desa/kelurahan. Pengaruh dana desa terbesar dirasakan oleh wilayah sebelah utara ibukota kabupaten, yaitu desa-desa di Kecamatan Kalukku, Papalang dan Sampaga. Sedangkan pengaruh paling kecil dari dana desa adalah desa-desa di Kecamatan Kalumpang.

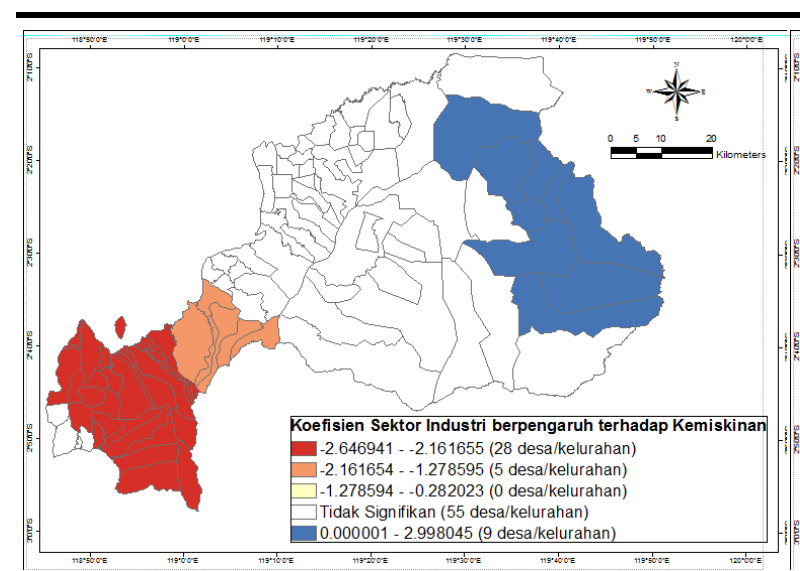

a. Industri

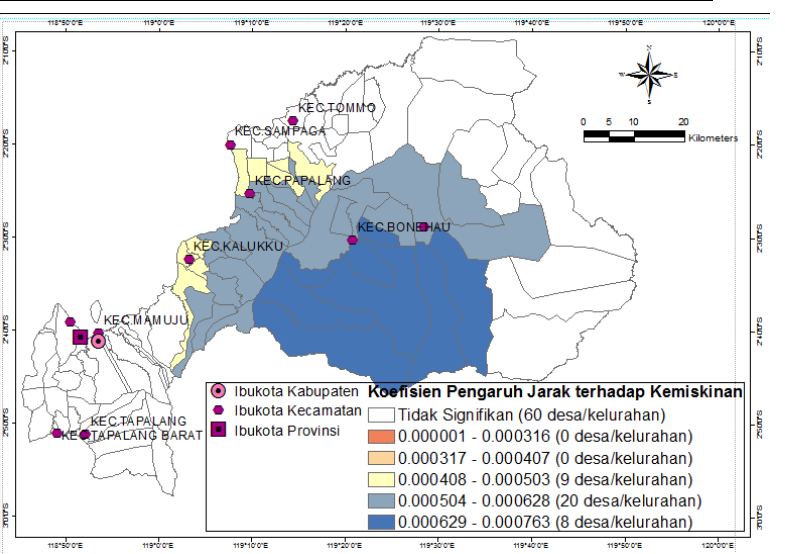

b. Jarak

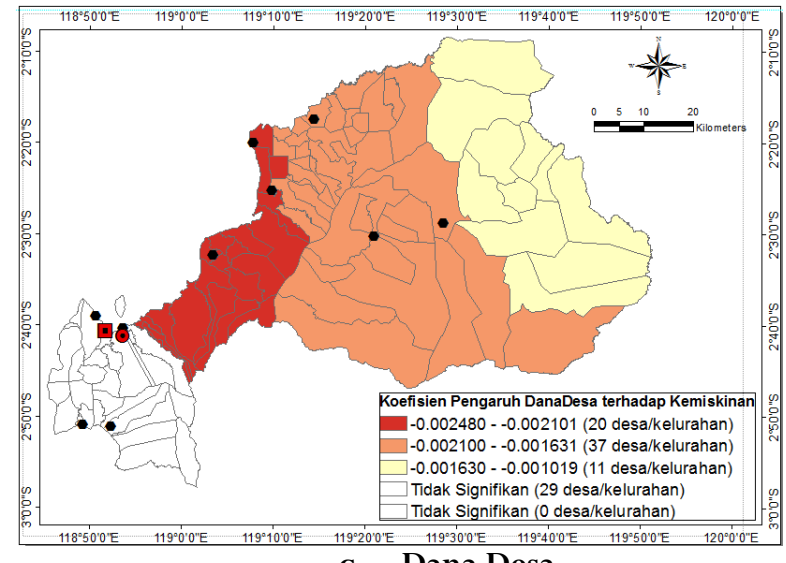

c. Dana Desa

Gambar 7. Sebaran Koefisien Variabel Industri, Jarak dan Dana Desa serta Lokasi Signifikan yang Berpengaruh terhadap Kemiskinan 
Dana desa diharapkan dapat menjadi pemicu meningkatnya perekonomian masyarakat, karena penggunaan utama dana desa untuk infrastruktur jalan, akan mendorong masyarakat dalam melaksanakan aktivitas perekonomiannya, seperti distribusi hasil pertanian, hasil industri dan aktifitas ekonomi lainnya. Penelitian Mangkuwinata (2017) juga menegaskan bahwa alokasi dana desa berdampak terhadap pemberdayaan masyarakat, sebagai pemberi dorongan, peluang, kesempatan, dan perlindungan untuk mengembangkan potensi daerahnya melalui berbagai aktivitas perekonomian sehingga diharapkan dapat menurunkan angka kemiskinan.

\section{Pemetaan Lokasi Signifikan Variabel yang Mempengaruhi Kemiskinan}

Kelebihan model GWR lainnya adalah adanya variasi wilayah berdasarkan pengelompokan kemiripan variabel yang berpengaruh. Pada Gambar 8 terlihat bahwa hasil GWR dan uji signifikansi terhadap masing-masing variabel di setiap lokasi menghasilkan 14 (empat belas) model untuk wilayah yang memiliki kesamaan variabel. Kebutuhan setiap wilayah dalam upaya mengurangi kemiskinan dapat diketahui berdasarkan variabel pada model yang dihasilkan. Untuk setiap wilayah dapat ditentukan faktor-faktor yang dapat mendukung upaya mereduksi kemiskinan. Hal ini menunjukkan perlu adanya perlakuan berbeda antara satu wilayah dengan wilayah lainnya dalam mengalokasikan program sertifikasi tanah, kebijakan penggunaan lahan pertanian dan program penanggulangan kemiskinan lainnya seperti dana desa dan pengembangan industri kecil dan mikro.

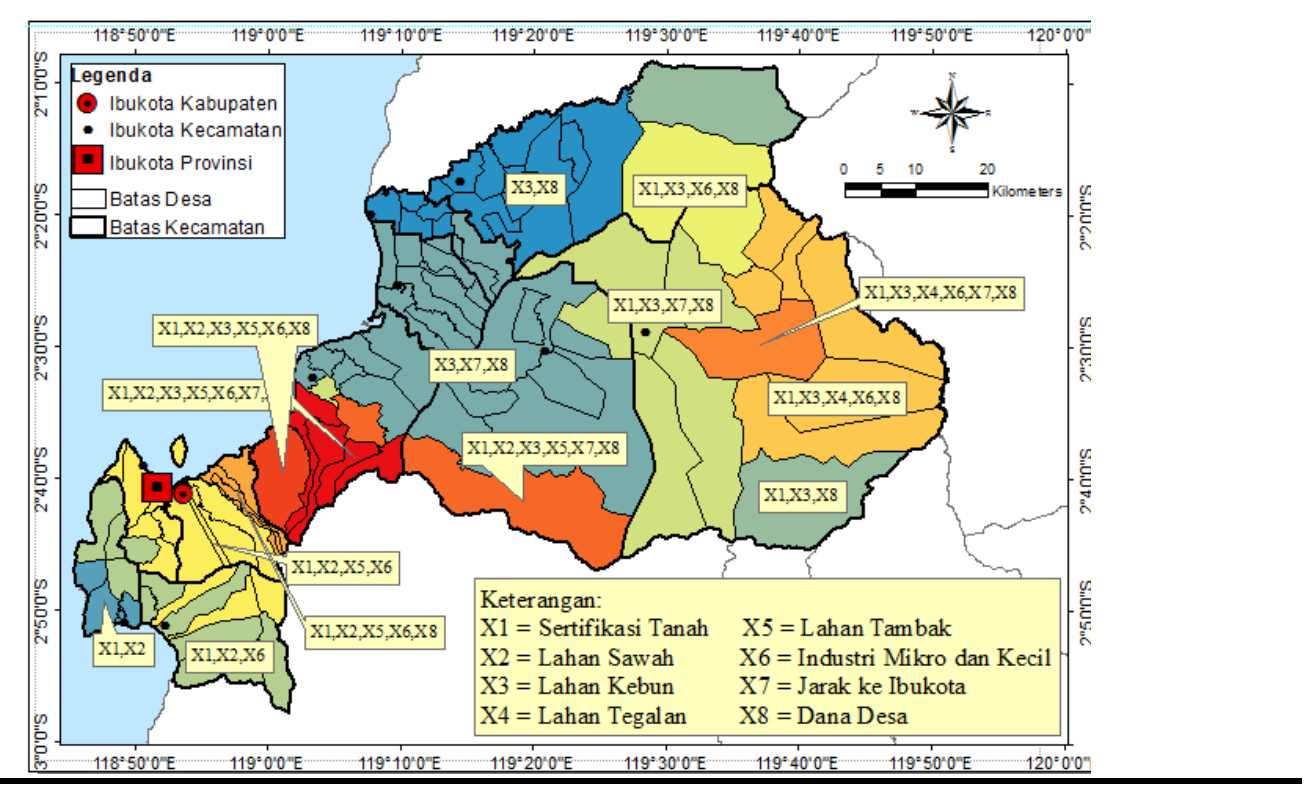

Gambar 8. Sebaran Desa/Kelurahan yang Memiliki Kesamaan Variabel Signifikan

Implikasi kebijakan, untuk wilayah yang memiliki tingkat kemiskinan tinggi di Kabupaten Mamuju, dimana dari hasil analisis Moran Lokal Anselin didapatkan dua kelompok high-high cluster yang ditemukan di wilayah Kecamatan Kalumpang, kebijakan penanggulangan kemiskinan dapat dilakukan melalui pengalokasian program sertifikasi tanah untuk semua desa/kelurahan, kebijakan pengembangan lahan kebun dan perkebunan serta penambahan dana desa yang selanjutnya lebih efektif diarahkan untuk pembangunan infrastruktur jalan, sehingga permasalahan jarak dapat teratasi. Sedangkan pengembangan industri kecil sepertinya bukan kebijakan yang efektif wilayah ini jika perbaikan akses jalan ke wilayah ini belum dilaksanakan. Hasil ini sejalan dengan studi 
Yudha (2017) bahwa pembangunan infrastruktur jalan dapat mendorong perkembangan desa dan menurunkan kemiskinan. Generalisasi kebijakan tanpa memperhatikan variasi pengaruh masing-masing parameter di wilayah yang berbeda akan memberikan dampak pada upaya percepatan penanggulangan kemiskinan dalam mereduksi kemiskinan.

\section{KESIMPULAN}

Kemiskinan di Kabupaten Mamuju menunjukkan keterkaitan kemiskinan antar desa/kelurahan dan pola spasial sebaran kemiskinan bersifat menggerombol (clustered). $\mathrm{Hal}$ ini menunjukkan adanya klusterisasi tingkat kemiskinan pada wilayah yang memiliki nilai pengamatan kemiskinan yang relatif sama dan letaknya saling berdekatan atau bertetangga. Tingkat kemiskinan di Kabupaten Mamuju tidak merata dan bersifat berkelompok, terbukti walaupun tingkat kemiskinan Kabupaten Mamuju cukup rendah, yaitu $6.7 \%$, tetapi terdapat hampir $30 \%$ desa/kelurahan memiliki tingkat kemiskinan $>12.4 \%$ hingga mencapai $56 \%$.

Sertifikasi tanah terbukti dapat mempengaruhi tingkat kemiskinan desa/kelurahan di 56 desa/kelurahan. Lahan pertanian terbukti cenderung berpengaruh dalam mengurangi kemiskinan. Penggunaan lahan kebun memberikan pengaruh terbesar terhadap kemiskinan, kemudian disusul penggunaan lahan tambak dan lahan tegalan/ladang. Sedangkan penggunaan lahan sawah belum terbukti di semua wilayah sebagai faktor yang dapat menurunkan kemiskinan. Peningkatan luasan lahan kebun, tambak dan tegalan di desa/kelurahan yang sesuai dengan lokasi signifikan mempengaruhi kemiskinan merupalan kebijakan yang tepat dalam usaha mengurangi angka kemiskinan. Semakin jauh jarak dari ibukota kabupaten memiliki kecenderungan bertambahnya tingkat kemiskinan, penambahan dan perbaikan akses jalan antar wilayah merupakan salah satu solusi. Peningkatan industri mikro dan kecil dan alokasi dana desa di setiap desa juga dapat menurunkan tingkat kemiskinan di wilayah desa tersebut.

\section{DAFTAR PUSTAKA}

Adetayo, AO. (2014). Analysis of Farm Households Poverty Status in Ogun States, Nigeria. Asian Economic and Financial Review. 4(3):325-340.

Amri, S., Ikhbar, S., Muzakkir. (2016). Strategi Pengentasan Kemiskinan melalui Produksi Usahatani Padi Sawah untuk Peningkatan Pembangunan Perekonomian Masyarakat Kabupaten Aceh Besar. Serambi Saintia. 4(2):19-25.

Anselin, L. (1988). Spatial Econometrics: Methods and Models. Netherlands Kluwer Academic Publisher. ISBN10: 9024737354.

Artino, A. (2017). Keterkaitan Dana Desa terhadap Kemiskinan di Kabupaten Lombok Utara [tesis]. Bogor (ID): Institut Pertanian Bogor.

Baiyegunhi, LJS dan Fraser, GCG. (2014). Poverty Incidence among Smallholder Farmers in the Amathole District Municipality, Eastern Cape Province, South Africa. J Hum Ecol. 46(3): 261-273 (2014)

[BPS] Badan Pusat Statistik. (2016). Data dan Informasi Kemiskinan Kabupaten/Kota 2015. Jakarta (ID): BPS.

[BPS Kab.Mamuju] Badan Pusat Statistik Kabupaten Mamuju. (2016). Statistik Daerah Kabupaten Mamuju 2016. Mamuju (ID): BPS Kab Mamuju.

Fotheringham, A.S., Brunsdon, C., Charlton, M. 2002. Geographically Weighted Regression: The Analysis of Spatially Varying Relationships. New York: John Wiley \& Sones,Ltd.

Juanda, B. (2009). Ekonometrika, Pemodelan dan Pendugaan. Bogor (ID): IPB Pr.

Mangkuwinata, SMI. (2017). Dampak Alokasi Dana Desa terhadap Pemberdayaan Ekonomi Masyarakat Desa Matanglumpangdua Meunasah Dayah Kecamatan Peusangan Kabupaten Bireun. Jurnal Kebangsaan. 6(12):13-21.

Nashwari, IP. (2016). Analisis Kemiskinan Petani Tanaman Pangan di Provinsi Jambi dan Jawa Barat menggunakan Geographically Weighted Regression [disertasi]. Bogor (ID): Institut Pertanian Bogor.

Nurwati, N. (2008). Kemiskinan: Model Pengukuran, Permasalahan dan Alternatif Kebijakan. Jurnal Kependudukan Padjajaran. 10(1):1-11. 
Permatasari, N., Priyarsono, D.S., Rifin, A. (2016). Perencanaan Pembangunan Ekonomi Wilayah Berbasis Pertanian dalam Rangka Pengurangan Kemiskinan di Kalimantan Barat. Jurnal Agribisnis Indonesia. 4(1):27-42.

Susila, AR. (2011). Analisis Sebaran Kemiskinan dan Faktor Penyebab Kemiskinan di Kabupaten Lebak [tesis]. Bogor (ID): Institut Pertanian Bogor.

Yudha, EP. (2017). Implementasi Pengelolaan Keuangan Desa dan Pengaruhnya terhadap Kinerja Pembangunan Perdesaan: Studi Kasus Kabupaten Pandeglang-Banten [disertasi]. Bogor (ID): Institut Pertanian Bogor. 